\title{
A REVIEW ON CHALLENGES AND SUSTAINABLE APPROACH FOR THE MUNICIPAL SOLID WASTE MANAGEMENT IN KOKRAJHAR TOWN
}

\author{
Omem Paron \\ Department of Civil Engineering, CIT, Kokrajhar, Assam, India \\ Dr. Ajay Bharti \\ Department of Civil Engineering, NERIST, Nirjuli, Arunachal Pradesh, India
}

\begin{abstract}
A huge quantity of MSW is generated in Kokrajhar town as compare to its growth rate of population. The open dumping and open burning of solid waste in Kokrajhar town pose a threat to vital components of environment and wellbeing of human welfare. The situation is aggravated by dumping of solid wastes in the drains of adjoining the roads which leads to the blockage of those drains due to which various severe problems such as artificial flood frequently occurs during the rainy days. Waste management of Kokrajhar town is one of the problems which have to tackle in scientific and sustainable way. Kokrajhar Municipality Board (KMB) is making an effort to improve waste management in this region by door to door collection of all the ten wards, still there are lacuna as the result of which significant success have not recorded. The field study was carried out to determine the quantity and characteristics of waste and concluded that the waste composition have higher percentage of organic waste which can be efficiently used as organic manure through biological decomposition process where as recycling and recover would be one of the best options for the inorganic matter of waste. This paper underlines the various factors responsible for the inefficient waste management and providing sustainable solution for the waste management in Kokrajhar town.
\end{abstract}

Keywords: Kokrajhar town, MSWM, Sustainable approach, Composting, Open dumping, Challenges, Recovery.

Cite this Article: Omem Paron And Dr. Ajay Bharti, A Review on Challenges and Sustainable Approach for The Municipal Solid Waste Management in Kokrajhar Town, International Journal of Advanced Research in Engineering and Technology, 10(1), 2019, pp 200-205

http://iaeme.com/Home/issue/IJARET?Volume $=10 \&$ Issue $=1$ 
A Review on Challenges and Sustainable Approach for The Municipal Solid Waste Management in Kokrajhar Town,

\section{INTRODUCTION}

The term solid waste includes all those solid and semisolid materials that are discarded by community. The solid waste generated through domestic and commercial activities is classified as Municipal Solid Waste [1]. The Municipal Solid Waste is disposed of by the municipal corporation and such local bodies. The safe disposal of solid waste of a society was not a serious problem as long as the population was small and the land available for assimilation of waste was large. Although the natural processes possess enough capacity to dilute, disperse, degrade, absorb or otherwise dispose of the unwanted waste, but that capacity has now come under tremendous stress due to the enormous quantities of waste being generated by the modern society. India similarly faces an uphill task for controlling pollution of all kinds such as water, air, and land pollution. The solid waste management was never taken up seriously either by public or by concerned authorities, which resulted in piling up of waste generation threaten the wellbeing of health and environment [2] [3]. Municipal waste management in developing nations is still at infancy and faces numerous challenges which can evaluate based on a) inadequate service coverage and operational inefficiencies of services, b) limited utilization of recycling activities, c) inadequate landfill disposal, and d) inadequate management of hazardous and healthcare waste [4].

The msw generation in Kokrajhar town is mainly from domestic waste which includes household waste, waste from markets, commercial area and institutional waste which includes waste from colleges, schools, office and other establishments. Kokrajhar Municipality Board (KMB) have been trying their level best to improve waste management in this region by door to door collection of ten wards covering 8000 households and each and every household are given two disposable bins one for Solid waste and the other for liquid waste management for proper garbage disposal [5], still there are lacuna which is obstructing their efforts. The area close to the disposal site is highly prone to toxicity, affecting benthic communities and over all environmental pollution [6] [7] [8] and also resource depletion can be caused by indiscriminate dumping of waste [10] [8].

The Success of any Waste Management system is directly related to its Disposal efficiency. To dispose waste in efficient way an appropriate infrastructure of technology, trained Manpower and availability of land is required. Methods which are commonly adopted for the disposal of solid waste are open dumps, landfills, incineration and composting. Selection of proper disposal method is necessary \& primarily it depends on the 'quantity of MSW generated $\&$ type of waste to be disposed. From the field investigation it has been observed that open dumping at disposal site and open burning is the practice for waste management in Kokrajhar town which is very unscientific approach. Which has cause negatively impact the near the vicinity [11]. The investigation has shown that approximately $63.3 \%$ of total solid is biodegradable followed paper and plastics and other inert materials.

The aim of this presentation is to propose suggestions to improve existing waste management of Kokrajhar town, to highlight the challenges faced by Kokrajhar Municipality Board also focus some of the waste management techniques.

\section{STUDY AREA}

Kokrajhar is one of administrative districts of Assam with $2.85 \%$ of the state population and is the gateway to Northeast India. The Kokrajhar town is the districts headquarter of Bodoland Territorial Council, created on 10th February 2003 comprising of four districts viz. Kokrajhar town, Chirang, Baska, Udalguri.The Kokrajhar district occupies an area of $3,169.22 \mathrm{~km}^{2}$. Kokrajhar district lies within $89^{\circ} 46^{\prime}$ East to $90^{\circ} 38^{\prime}$ 'East and $26^{\circ} 19^{\prime}$ 'North to $26^{\circ} 54^{\prime}$ North Latitude.it is located at $26.4^{\circ} \mathrm{N} 90.27^{\circ} \mathrm{E}$ and has an average elevation of 38 metres. Kokrajhar 
district is located on the northern bank of the Brahmaputra River and along the bank of Gourang River. Common languge spoken in the region are Bodo, Assamese, English, Hindi, Bangla, and other local dialects. The district is stretches to the international border with the Kingdom of Bhutan. It is bounded on the north by Bhutan and by West Bengal on the west; the district of Dhubri in the south and in the east by Chirang district. the kingdom of Bhutan is intricately link with the district in many vital aspects of life. As per 2011 census Kokrajhar district has a population of 34136. The district has a population density of 280 inhabitants per square kilometres .Its population growth rate over the decade 2001-2011 was 5.19\%.Kokrajhar has a sex ratio of 958 females for every 1000 males and a literacy rate of $66.63 \%$. The district is well connected with the state capital and other district headquarters through proper roadways, railways and river ways. The district is about $250 \mathrm{~km}$ away from the state capital Dispur, Guwahati.

\section{WASTE MANAGEMENT TECHNIQUE OF KOKRAJHAR TOWN}

At present Kokrajhar town has 10 wards, the Kokrajhar Municipality Board (KMB) is the concerned authority for managing the solid waste generated from this area. The total waste generation from the Kokrajhar town alone is approximately 14MT/day [12] which is more than the expected generation of solid waste from the population of 34316 [13]. The waste from the various ward of this town are collected by tractors, dumper, tri cycles every day with the help of sweeper and without segregation the solid waste at disposal site of Kokrajhar town, which lies by the side of Gaurang river.

From survey it was observed in the market area Majority of sellers are seen collecting the wastes in a particular and wait for the sweepers to come and few of them have private collection system and emptying them in public dumping areas. The very familiar picture seen is that sellers generally collect their garbage and keep them in front of their shops and then they simply burn it or Simply throw their solid wastes in the drains adjoining the roads(fig 1) which leads to the blockage of those drains due to which various severe problems occurs such as artificial flood during rainy days, spreading of disease like malaria etc. For the convenience of collection, the whole area has been divided into numbers of zone and for each of the zone private contractors were given the charge for maintaining cleanliness in their particular areas by the municipality board of Kokrajhar town. They are given the charge for proper collection and disposal of garbage in their own areas on daily basis and thus contractors have appointed their own sweepers for carrying out the proper collection and disposal of garbage in their respective areas. From the field visit it was observed open dumping (fig 2) is the practice of disposal of MSW of Kokrajhar town which is considered unscientific approach.

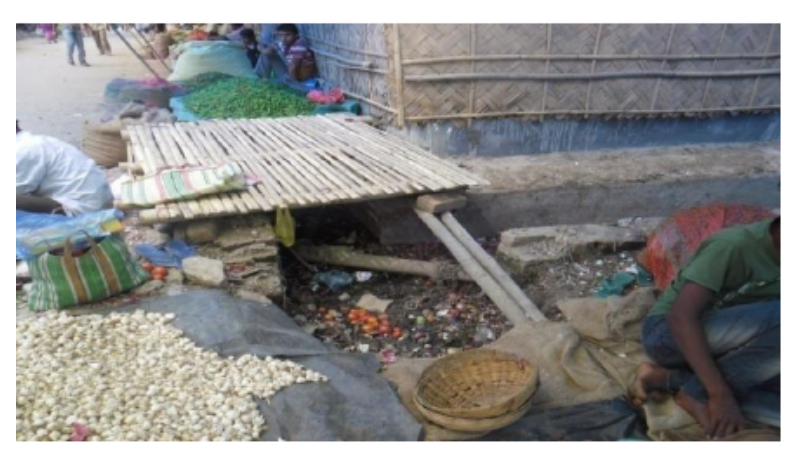

Figure 1 Throwing of waste into drain

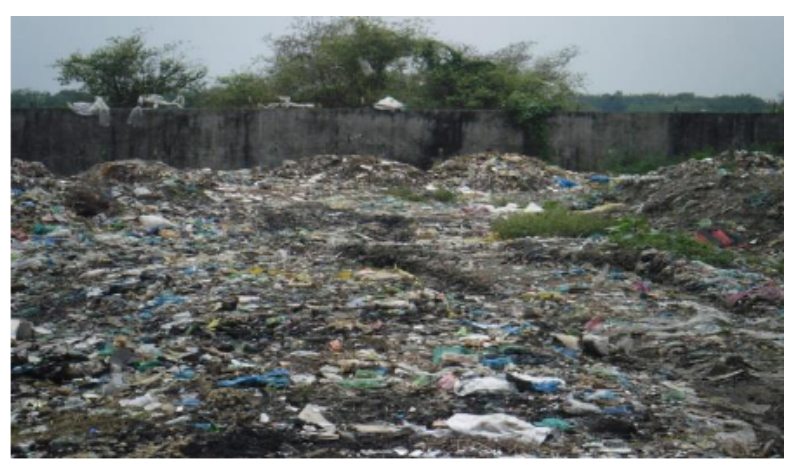

Figure 2 Disposal site of Kokrajhar town

Since the disposal site lies near the Gaurang River, covering an area of about 800 sq.mtr. This area is commonly known as samshanghat which is about $1.5 \mathrm{~km}$ away from Kokrajhar daily 
A Review on Challenges and Sustainable Approach for The Municipal Solid Waste Management in Kokrajhar Town,

market. it is very obvious the possibility of contaminant reaching from the open dumping, ground water contamination and emissions of anthropogenic greenhouse gas. The unscientific disposal of msw causes an adverse impact on the vital components of environment along with human health [14] Waste management of Kokrajhar town is shown in Fig (3).

\section{Storage Collection Transportation Disposal at Site}

Figure 3 Waste management of Kokrajhar town

\section{EFFECTIVE WASTE MANAGEMENT IN KOKRAJHAR TOWN “A CHALLENGE"}

Kokrajhar town is one of very fast-growing town, like any other developing town. Within a stretch of few years many development activities have been taken place. Population growth and urbanization in this area result in huge generation of solid waste, due to the lack of suitable technology the solid waste of this area is directly goes to the open dumping and increase additional load on disposal site. The consideration of any waste treatment techniques depends on several factors such as quantity and composition of waste which vary from time to time in different municipalities [14], available technology, and land availability for disposal [15].

From the field investigations some of the factors listed below are the major challenges before appropriate municipal waste management of Kokrajhar town are A) lack of skill of existing technology, suitable technologies and lacking the knowledge of technology for the effective waste management, still the strategy of waste management in Kokrajhar town is open dumping and open burning in disposal site. The investigation shows major portion of the waste generated from the Kokrajhar town is biodegradable in nature, which can convert as compost. The government must focus and investment on suitable technology for effective waste management, generation of revenue, job creation and protection of environment and wellbeing of public. B) The lack environmental education and awareness in the Kokrajhar town is one of the factors of inefficient waste management, the government should implement program that will increase the knowledge of the environment to the general public, through this programs, and general public should gain knowledge about the proper waste management practice, how their action affected the environment. C) The effective waste management involves the participation of all the stakeholders. Poor funding from the agency for the payment of salaries to the staff and private contractors and maintenance of trucks and trolley etc is one of the factors which are hindering the effective waste management in Kokrajhar town. D) Unlike some countries, no incentives are given to the residents of Kokrajhar town for recycling their waste. Providing incentives will encourage the residents to recycle the waste, this will influence the waste generation.

\section{ASYSTEMATIC AND SUSTAINABLE WASTE MANAGEMENT APPROACH}

An up-gradation to the existing waste management in Kokrajhar town is the need of an hour. Kokrajhar municipality board has recently started door to door collection of waste from all over the town, with minimal charges which has come as a positive decision for the authority. The government and the concern authority should focus more on awareness programs regarding sorting of waste at source by residents and implementing technology for recovery of material from the waste through composting process. The compost material from composting process 
will help in improving the crop productivity [16] the proposed waste management approach is shown in Fig (4)

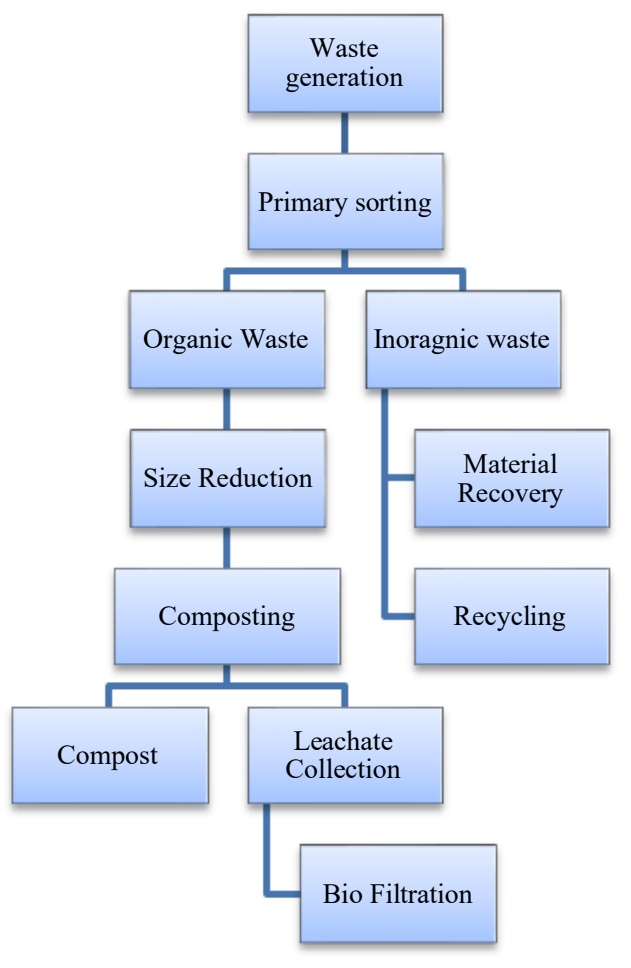

Figure 4 A Proposed Waste Management Approach for Kokrajhar town.

\section{CONCLUSION}

Kokrajhar town generates high percentage of biodegradable waste which can be efficiently managed by biological decomposition process such as composting and biofiltration which helps in improving the crop productivity and revenue generation of the Kokrajhar area. Kokrajhar Municipality Board (KMB) is making an effort to improve waste management in this region by door to door collection of all the ten wards, still there are lacuna as the result of which significant success have not recorded. It is necessary for the government and all the stake holders to be participate in waste management for achieving the goals. Recycling and recovery from inorganic waste should prefer over the open dumping or open burning of waste. The proposed systematic and sustainable approach for waste management is designed.

\section{REFERENCES}

[1] S.K. Garg Sewage Disposal and Air Pollution Engineering Environmental Engg. II

[2] Mazumdar, N.B (1994), "Municipal solid waste management the Indian perspectives," journal of Environment Monitor, Vol. 12(2) pp. 257-269.

[3] Chouhan B.M and B.K Reddy (1996) "Bio-energy scenario in India, "Journal IREDA News, Vol. 7(1), pp. 20-27.

[4] Zurbrugg C., (2003), Solid Waste Management in Developing Countries, EAWAG,on lineat:http://www.eawag.ch/organisation/abteilungen/sandec/publikationen/publications_swm/ downloads_swm/basics_of_SWM.pdf.

[5] Kokrajhar municipality board, Kokrajhar BTAD, Assam.

[6] Ukpong ECU, Udo EA, Umoh IC (2015) "Characterization of materials from Aba waste dumpsites” Int. J. Eng. Appl. Sci. 6, 1-10. 
A Review on Challenges and Sustainable Approach for The Municipal Solid Waste Management in Kokrajhar Town,

[7] Ayuba KA, Manaf LA, Sabrina AH, Azmin SWN (2013) "Current status of municipal solid waste management practice in FCT Abuja." Res. J. Environ. Earth Sci. 5, 295-304

[8] Ezerie Henry Ezech, Chima George Nwabuko, Ogbonna Chidi Enyinnaya, Chibunna John Babington (2017) "Municipal solid waste management in Aba, Nigeria: Challenges and prospects" Enviorn. Eng. Res.22(3), 231-236

[9] Nkwachukwu OI Chidi NI, Charles KO (2010) "Issues of roadside disposal habit of municipal solid waste, environmental impacts and implementation of sound management practices in developing country Nigeria”. Int. J. Environ. Sci. Dev. 5, 409-418.

[10] Paron Omem, Bharti Ajay (2017) "A case study on solid waste disposal site in Kokrajhar town" journal of construction and building material engineering" Vol 3 (1), pp, 1-4.

[11] Assam Urban Solid waste management report (2018)

[12] Kokrajhar district Census of India 2011 District Secretariat, Kokrajhar.

[13] Rathi S (2006) "Alternative approaches for better municipal solid waste management in Mumbai, India" Journal of waste management .26 (10), 1192-1200.

[14] UNESCO (1996) "Management of solid waste- Multimedia postgraduate course in Environmental Engineering" UNESCO publications, Paris.

[15] Sabbas T, Polettini A, Pomib R (2003) "Management of municipal solid waste incineration residues. Waste Management" 23, 61-88.

[16] Schaub S, Leonard J (1996) "Composting an alternative waste management option for food processing industries Trends Food Sci. Technol.” 7, 263-268.

[17] Bernal MP, Alburquerque J, Moral R (2009) “Composting of animal manures and chemical criteria for compost maturity assessment. A review” Bioresour. Technol. 100, 5444-5453.

[18] Arti Pamnani and Meka Srinivasarao, Municipal Solid Waste Management in India: A Review and Some New Results, International Journal of Civil Engineering and Technology (IJCIET), Volume 5, Issue 2, February (2014), pp. 01-08

[19] O. O. Elemile, B.T Ogunsemi, M. K. C. Sridhar, O.O Akinola and A.O. Coker Performance Assessment of A Carbon Dioxide Extractor In A Solid Waste Management Facility In Akure, Nigeria, Journal of Civil Engineering and Technology, 9(11), 2018, pp. 1252-1268

[20] G.Vaisali, K.Sai Bhargavi and Satish Kumar, Smart Solid Waste Management System by Iot, International Journal of Mechanical Engineering and Technology 8(12), 2017, pp. 841-846

[21] Sesha Sai Ratnamala Bommareddy and SS. Asadi, Solid Waste Management Through PublicPrivate Partnership Model. International Journal of Civil Engineering and Technology, 8(1), 2017, pp. 263-272

[22] S. Senith, Venkata Ramesh Reddy V and Eunice S, Technologies in Environmental Regulation - Solid Waste Management Review, International Journal of Civil Engineering and Technology, 9(6), 2018, pp. 1213-1220 